\title{
Program Kemitraan Universitas bagi Pengurus Kelompok Tani Sumber Rejeki III untuk Mengelola Administrasi Keuangan Syariah
}

\author{
R. Arri Widyanto ${ }^{1}$, Sunarni², Andi Triyanto ${ }^{3}$ \\ Universitas Muhammadiyah Magelang ${ }^{1,2,3}$ \\ arri_w@ummgl.ac.id ${ }^{1}$, Sunarni@ummgl.ac.id ${ }^{2}$, andi_rabbani@ummgl.ac.id ${ }^{3}$
}

\begin{abstract}
Sumber Rejeki III Farmers Group is an organization of farmers in Turen, Kradenan Village. The administrators are mainly farmers. The level of education of the management of farmer groups is high school and equivalent. The problem that occurs in this farmer group is that there are no administrators who can operate the computer, so the administration has not been well organized. All documents are written manually using separate books and note papers. Making reports of Lembaga Keuangan Mikro (LMK) often has difficulty because they have to collect from many records and often records are missing, causing financial report to be invalid. The objectives of this partnership program are: (a) Giving skills to operate computers. (b). Improving ability in recording and making financial report in sharia. The methods used are: (a) preparation, $(b)$ implementation, (c) evaluation phase and follow-up. The results of this activity, the average level of mastery of computer utilization for administrative activities are: Mastering $(0.78 \%)$ and Selfmastering (0.22\%). This programs output is to increase the ability of partners to use computer applications for administration to $70 \%$ of from 50, and financial system of these farmer groups' LKM use the sharia accounting system.
\end{abstract}

Keywords: farmer group; computer applications; Islamic accounting systems.

\begin{abstract}
Abstrak
Kelompok Tani Sumber Rejeki III merupakan organisasi yang mewadahi petani-petani di dusun Turen Desa Kradenan. Para pengurusnya rata-rata pekerjaan utamanya adalah petani. Tingkat pendidikan pengurus kelompok tani SMA dan sederajat. Tingkat penguasaan pengoperasian komputer $0 \%$ dari seluruh pengurus. Permasalahan yang terjadi pada kelompok tani ini adalah tidak ada pengurus yang bisa mengoperasikan komputer, sehingga administrasinya belum tertata dengan baik. Semua dokumen dituliskan secara manual dengan menggunakan buku-buku dan kertas-kertas catatan yang terpisah-pisah. Pembuatan laporan Lembaga Keuangan Mikro (LKM) sering mengalami kesulitan karena harus mengumpulkan dari banyak catatan dan sering ada catatan yang hilang, sehingga menyebabkan laporan keuangan menjadi tidak valid. Tujuan dari program kemitraan ini adalah: (a) Memberi keterampilan mengoperasikan komputer. (b). Meningkatkan kemampuan dalam pencatatan dan pembuatan laporan keuangan secara syariah. Metode yang digunakan : (a) tahap persiapan, (b) tahap pelaksanaan, (c) tahap evaluasi dan tindak lanjut. Hasil dari kegiatan ini, rata-rata tingkat penguasaan pemanfaatan komputer untuk kegiatan administasi adalah: Menguasai $(0,78 \%)$ dan Cukup menguasai $(0,22 \%)$. Luaran PKU ini adalah
\end{abstract}


meningkatkan kemampuan mitra dalam menggunakan aplikasi komputer untuk administrasi menjadi $70 \%$ dari target semula 50\% dan system keuangan LKM kelompok tani ini menggunakan sistem akuntansi syaria'ah.

Kata Kunci: : Kelompok tani; aplikasi computer; sistem akuntansi syariah

\section{A. PENDAhULUAN}

Kelompok Tani Sumber Rejeki III, berdiri tahun 2009 merupakan kelompok yang mewadahi petani-petani di dusun Turen Desa Kradenan. Awal berdirinya, kelompok tani ini memiliki anggota berjumlah 40 orang yang berasal dari dusun Turen dan sekitarnya. Seiring berjalannya waktu, terjadi mutasi anggota kelompok tani ada yang mengundurkan diri dan ada penambahan anggota baru. Saat ini anggota kelompok tani yang aktif berjumlah 45 orang yang kesemuanya berasal dari dusun Turen. Usia rata-rata pengurus kelompok tani berusia 48 tahun. Tingkat pendidikan semua pengurus kelompok tani SMA dan sederajat. Tingkat penguasaan pengoperasian komputer $0 \%$ dari seluruh pengurus.

Pengurus kelompok tani, belum memiliki kompetensi khusus, dalam bidang administrasi maupun keuangan. Kelompok tani ini, seperti kelompok tani yang lain merupakan organisasi nir laba sehingga para pengurusnya bekerja secara sosial. Hal ini menyebabkan setiap pergantian pengurus sering berjalan tidak lancar, karena orang yang dipilih sebagai pengurus tidak bersedia walaupun orang tersebut memiliki kemampuaan yang dibutuhkan kelompok tani.

Potensi yng dimiliki kelompok tani ini adalah sudah memiliki Lembaga Keuangan Mikro (LKM) yang digunakan anggotanya sebagai sarana simpan pinjam. Disaat musim tanam, para petani membutuhkan modal untuk menggarap sawahnya. Modal ini didapatkan dari LKM yang ada. Demikian pula bila ada sedikit kelebihan akan disimpan di LKM. Saat ini jumlah anggota LKM 30 Orang. Jumlah dana pinjaman maksimal Rp. 5.000.000,00 per orang. Modal awal LKM ini adalah Rp. 18.000.000,00 yang kesemuanya berasal dari kelompok tani. Pengelola LKM ini terdiri dari anggota kelompok tani dan pengurus kelompok tani.

Permasalahan yang terjadi pada kelompok tani ini adalah tidak ada pengurus yang bisa mengoperasikan aplikasi komputer, dalam bidang komputer aplikasi didefinisikan sebagai program siap pakai, program yang dibuat untuk melaksanakan suatu fungsi bagi pengguna. Istilah ini mulai perlahan masuk ke dalam istilah teknologi informasi semenjak tahun 1993 (Febrian Jack, 2002). Karena tidak ada yang bisa mengoperasikan komputer, sehingga administrasinya belum tertata dengan baik. Semua dokumen dituliskan secara manual dengan menggunakan buku-buku dan kertaskertas catatan yang terpisah-pisah. Terutama dalam pembuatan laporan LKM yang harus dilaporkan setiap bulan kepada kelompok tani, harus mengumpulkan dari banyak catatan dan tidak jarang ada catatan yang tercecer atau hilang yang menyebabkan laporan terutama laporan keuangan menjadi tidak valid. Selain itu sistem simpan pinjam yang ada, belum memenuhi unsur-unsur syariah sehingga perlu dibuatkan sistem keuangan yang syar'i sehingga terbebas dari sistem riba. Permasalahan dari kelompok tani ini adalah : 1) Semua pengurus kelompok 
tani tidak ada yang bisa mengoperasikan komputer, sehingga untuk membuat laporan harus menggunakan jasa pengetikan. 2). Undangan pertemuan rutin belum terdokumentasi, karena hanya diumumkan lewat pengeras suara di Masjid. 3). Buruknya metode pencatatan keuangan pada LKM sehingga sering terjadi jumlah uang tidak sesuai dengan catatan. 4). Sistem simpan pinjam belum dilaksanakan secara syariah, sehingga terdapat unsur riba.

\section{B. PELAKSAAAN DAN METODE}

Kegiatan Pengabdian kepada Masyarakat ini dilaksanakan dalam waktu 3 (tiga) bulan. Metode yang digunakan adalah pelatihan dan pendampingan, yang terbagi dalam tiga tahap yaitu : (1) tahap persiapan, (2) tahap pelaksanaan, (3) tahap evaluasi. Seperti terlihat pada gambar 1 berikut :

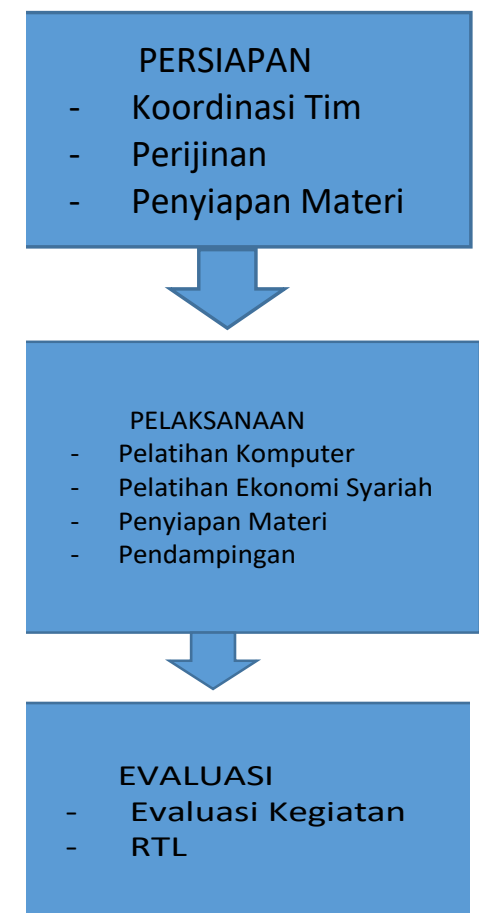

Gambar 1. Metode Kegiatan

Tahap Persiapan terdiri dari (a) Koordinasi team Universitas
Muhammadiyah dengan masyarakat sasaran, yaitu pengurus kelompok tani, membahas rencana kegiatan. (b). Menyiapkan perijinan. (c). Menyusun dan menyiapkan Materi Pelatihan dan Pendampingan.

Tahap Pelaksanaan dilakukan secara bertahap dengan melakukan kegiatan pertama memberi pelatihan tentang pemanfaatan microsoft office untuk kegiatan administrasi surat-menyurat. Pelaksanaan kegiatan ke-2, memberi pendampingan penyusunan administrasi kelompok tani. Pelaksanaan kegiatan ke-3 memberi pelatihan pengelolaan keuangan LKM menggunakan sistem ekonomi syariah. Kegiatan ke-4 memberikan pendampingan pengelolaan keuangan LKM.

Tahap evaluasi dilakukan dengan menguji secara praktik kemampuan menggunakan komputer untuk administrasi dengan materi microsoft word dan microsoft excel, untuk mengetahui peningkatan kemampuan setelah mengikuti pelatihan. Melakukan diskusi bersama pengurus kelompok tani terkait pelaksanaan kegiatan yang sudah dilakukan dan rencana tindak lanjut (RTL).

\section{HASIL DAN PEMBAHASAN}

Kegiatan PKU ini diawali dengan koordinasi tim dan pengurus kelompok tani, untuk menentukan jadwal kegiatan.

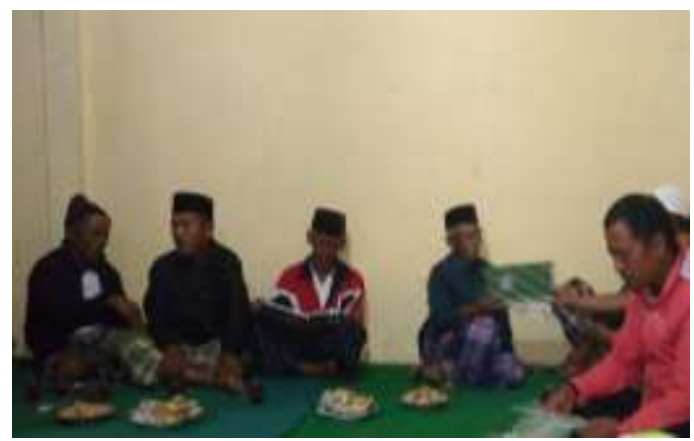

Gambar 2. Koordinasi Kegiatan Pengabdian 
Pelaksanaan Kegiatan pengabdian ini secara umum dibagi menjadi dua bagian, yaitu : (1). Pelatihan pemanfaatan komputer untuk administrasi menggunakan Microsoft Word dan Microsoft Excel. Materi yang diajarkan adalah materi-materi dasar berupa format dokumen, mengatur paragraf dan spasi, serta tabel. Selain itu berupa pelatihan mengelola surat-menyurat menggunakan fasilitas mail merge. Materi pelatihan Microsoft excel adalah dasar-dasar Microsoft Excel blok sel dan range serta copy dan paste cell, Format Cell yang digunakan untuk mengatur format angka, desimal, accounting dan Format tanggal menggunakan Date. Selain itu fungsi-fungsi sederhana seperti $=S U M$, $=\mathrm{AVERAGE},=\mathrm{MIN}$ dan $=\mathrm{MAX}$.

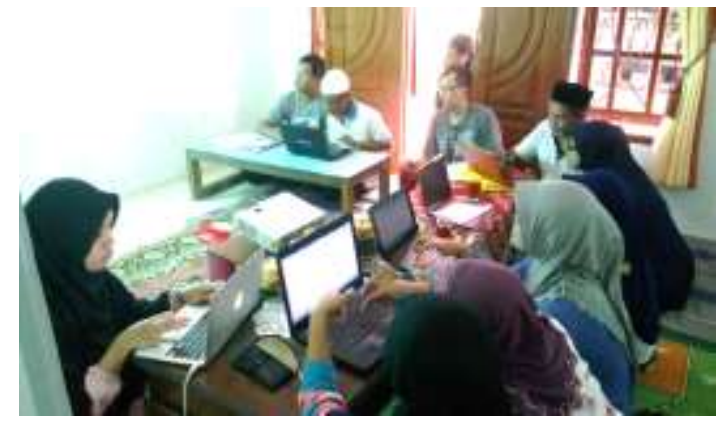

Gambar 3. Foto Kegiatan Pelatihan Komputer

(2). Pelatihan Administrasi Keuangan LKM atau Koperasi Kelompok Tani. Pelatihan ini meliputi dasar-dasar mu'amalah dan sya'riah. Kegiatan ini diawali dengan materi dasar berupa pemahaman kembali maslahmasalah aqidah, ibadah dan akhlaq kemudian dilanjutkan materi mu'amalah dan syariah. Peserta yang mengikuti kegiatan ini adalah semua anggota kelompok tani yang dilaksanakan hari Sabtu tanggal 2 Maret 2019. Materi berikutnya berupa penyusunan administrasi dan keuangan syariah yang meliputi dasar-dasar akuntansi syariah.

Pelatihan administrasi dan keuangan ini, bertujuan untuk menghasilkan laporan keuangan yang semestinya untuk kepentingan pengendalian serta pengawasan (Sumadi dkk, 2018). Laporan keuangan menurut Sutrisno (2013), merupakan hasil akhir dari proses akuntansi meliputi dua laporan utama yakni neraca dan laporan laba rugi.

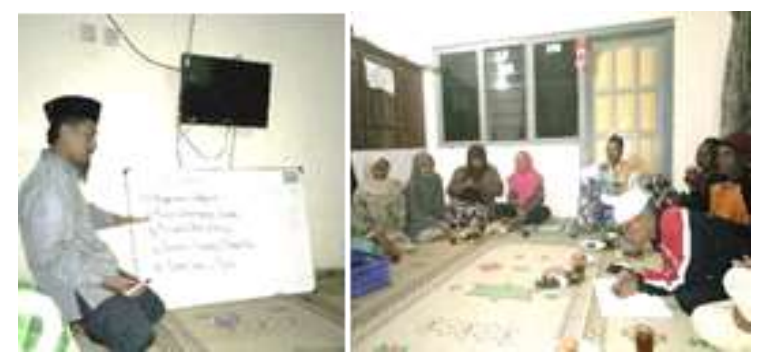

Gambar 4. Kegiatan Sosialisi Sistem Keuangan Syariah

Yusri Ikhwani, dkk, (2015) menyatakan : Hasil kegiatan yang langsung dapat dinilai oleh Tim Pengabdian adalah : (1). Peserta dapat belajar tentang menjalankan aplikasi Microsoft Word 2013. (2). Peserta dapat melakukan pembuatan surat, undangan dan menggunakan tool pada aplikasi Microsoft Word 2013. (3). Peserta dapat mempergunakan aplikasi Microsoft Word 2013 sesuai dengan keperluannya masing-masing.

Microsoft Word, merupakan aplikasi word processor adalah aplikasi yang digunakan untuk membuat dokumen (Kadir, Abdul, 2015). Versi-versi microsoft word ada banyak, diantaranya adalah versi 2013.

Pada kegiatan ini, dilakukan evaluasi dengan menguji secara praktek, dengan hasil dari evaluasi kegiatan pelatihan komputer didapat nilai seperti tabel berikut ini : 
Tabel 1. Nilai Hasil Evaluasi Pelatihan MS Word

\begin{tabular}{llrrr}
\hline No & Nama & $\begin{array}{r}\text { Ms. } \\
\text { Word }\end{array}$ & $\begin{array}{r}\text { Ms. } \\
\text { Excel }\end{array}$ & $\begin{array}{r}\text { Rata- } \\
\text { rata }\end{array}$ \\
\hline 1 & Paino & 76,5 & 75 & 75,75 \\
2 & Anjar Gunadi & 81 & 80 & 80,5 \\
3 & Tri Sulatri & 79 & 78 & 78,5 \\
4 & Suhari & 67,5 & 60 & 63,75 \\
5 & Wasiati & 70 & 65 & 67,5 \\
6 & Faidah & 90 & 90 & 90 \\
& Fatmawati & & & \\
7 & Sunarmi & 70 & 70 & 70 \\
8 & Suprayogo & 65 & 60 & 62,5 \\
9 & Endang SM & 85 & 90 & 87,5 \\
\hline
\end{tabular}

Tabel 2. Nilai Hasil Evaluasi Pelatihan MS Excel

\begin{tabular}{rlr}
\hline No & Nama & Nilai \\
\hline 1 & Paino & 75 \\
2 & Anjar Gunadi & 80 \\
3 & Tri Sulatri & 78 \\
4 & Suhari & 60 \\
5 & Wasiati & 65 \\
6 & Faidah & 90 \\
& Fatmawati & 70 \\
7 & Sunarmi & 60 \\
8 & Suprayogo & 90 \\
9 & Endang SM & \\
\hline
\end{tabular}

Tabel 3. Nilai Hasil Rata-rata

\begin{tabular}{llccr}
\hline & & \multicolumn{3}{c}{ MS Word } \\
\cline { 3 - 5 } No & \multicolumn{1}{c}{ Nama } & $\begin{array}{c}\text { Format } \\
\text { Dokumen }\end{array}$ & $\begin{array}{c}\text { Mail } \\
\text { Merge }\end{array}$ & $\begin{array}{c}\text { Rata- } \\
\text { rata }\end{array}$ \\
\hline 1 & Paino & 78 & 75 & 76,5 \\
2 & Anjar Gunadi & 82 & 80 & 81 \\
3 & Tri Sulatri & 80 & 78 & 79 \\
4 & Suhari & 70 & 65 & 67,5 \\
5 & Wasiati & 70 & 70 & 70 \\
6 & Faidah & 90 & 90 & 90 \\
& Fatmawati & & & \\
7 & Sunarmi & 70 & 70 & 70 \\
8 & Suprayogo & 65 & 65 & 65 \\
9 & Endang SM & 85 & 85 & 85 \\
\hline
\end{tabular}

Tabel . 4. Permasalahan Solusi dan Hasil Kegiatan

\begin{tabular}{|c|c|c|}
\hline Permasalahan & $\begin{array}{l}\text { Solusi yang } \\
\text { ditawarkan }\end{array}$ & $\begin{array}{c}\text { Hasil } \\
\text { Kegiatan }\end{array}$ \\
\hline $\begin{array}{l}\text { 1. Pengurus } \\
\text { kelompok } \\
\text { tani belum } \\
\text { memiliki } \\
\text { keterampilan } \\
\text { menggunakan } \\
\text { komputer }\end{array}$ & $\begin{array}{l}\text { Memberi } \\
\text { pelatihan } \\
\text { komputer } \\
\text { menggunakan } \\
\text { aplikasi } \\
\text { perkantoran. }\end{array}$ & $\begin{array}{l}\text { Menguasai : } \\
8 \text { Orang } \\
(0,89 \%) \\
\text { Cukup } \\
\text { menguasai : } 1 \\
\text { Orang } \\
(0,11 \%)\end{array}$ \\
\hline $\begin{array}{l}\text { 2. Kesulitan } \\
\text { dalam } \\
\text { membuat } \\
\text { undangan } \\
\text { pertemuan } \\
\text { rutin. }\end{array}$ & $\begin{array}{l}\text { 2. Memberi } \\
\text { pelatihan } \\
\text { membuat } \\
\text { surat berantai. }\end{array}$ & $\begin{array}{l}\text { Menguasai : } \\
7 \text { Orang } \\
(0,78 \%), \\
\text { Cukup } \\
\text { menguasai : } 2 \\
\text { Orang } \\
(0,22 \%)\end{array}$ \\
\hline 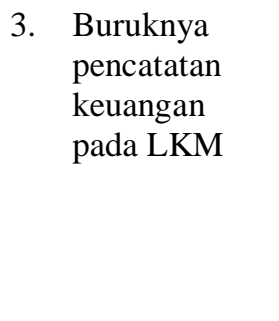 & $\begin{array}{l}\text { 3. Memberi } \\
\text { pelatihan } \\
\text { pengelolaan } \\
\text { administrasi } \\
\text { dan keuangan } \\
\text { menggunakan } \\
\text { aplikasi } \\
\text { lembar sebar. }\end{array}$ & $\begin{array}{l}\text { Menguasai : } \\
6 \text { Orang } \\
(0,67 \%), \\
\text { Cukup } \\
\text { menguasai : } 3 \\
\text { Orang } \\
(0,33 \%)\end{array}$ \\
\hline $\begin{array}{l}\text { 4. Sistem } \\
\text { simpan } \\
\text { pinjam masih } \\
\text { mengandung } \\
\text { unsur riba. }\end{array}$ & $\begin{array}{l}\text { 4. Membuat } \\
\text { sistem } \\
\text { keuangan } \\
\text { syar'i. }\end{array}$ & $\begin{array}{l}\text { Pembukuan } \\
\text { kelompok } \\
\text { tani } \\
\text { menggunakan } \\
\text { sistem } \\
\text { akuntansi } \\
\text { syariah }\end{array}$ \\
\hline
\end{tabular}

Hasil evaluasi dari kegiatan tersebut secara umum adalah sebagai berikut : Rata-rata tingkat penguasaan pemanfaatan komputer untuk kegiatan administasi adalah sebagai berikut : Menguasai : 7 Orang (0,78\%), Cukup menguasai : 2 Orang $(0,22 \%)$

\section{PENUTUP}

\section{Simpulan}

Dari hasil kegiatan PKU yang sudah dilaksanakan dapat disimpulkan sebagai berikut : Kegiatan-kegiatan ini menyelesaikan permasalahan yang mengacu dari hasil identifikasi dan diskusi yang dilaksanakan oleh tim pengabdian dan 
pengurus kelompok tani. Hasil yang diperoleh adalah meningkatnya kemampuan peserta pelatihan dari semula belum terukur atau $(0 \%)$ menjadi $(0,89 \%)$ menguasai dan cukup menguasai $(0,11 \%)$ untuk materi pelatihan dasar-dasar microsoft word.

Tingkat penguasaan terhadap materi mail merge adalah : menguasai $(0,78 \%$ dan , cukup menguasai $(0,22 \%)$, sehingga bisa diimplementasikan pada pembuatan undangan pertemuan rutin kelompok tani. Kemampuan menggunakan Micrososft Excel dengan tingkat keberhasilan sebagai berikut : menguasai $(0,67 \%)$, cukup menguasai $(0,33 \%)$. Hasil evaluasi dari kegiatan tersebut secara umum adalah sebagai berikut : Ratarata tingkat penguasaan pemanfaatan komputer untuk kegiatan administasi adalah sebagai berikut : Menguasai $(0,78 \%)$ dan Cukup menguasai $(0,22 \%)$. Target $50 \%$ dari seluruh pengurus kelompok tani yang memiliki keterampilan dalam menggunakan komputer tercapai.

\section{Saran}

Kesadaran pengurus kelompok tani harus ditingkatkan terutama dalam mengelola administrasi. Diadakan pelatihan komputer tingkat lanjut dan pendampingan yang intensif dalam bidang pengelolaan keuangan syariah.

\section{Ucapan Terima Kasih}

Terimakasih diucapkan kepada Ketua Kelompok Tani sumber Rejeki III, yang telah memberikan ijin untuk melaksanakan program pengabdian ini. Terimakasih juga kepada Ketua LP3M dan Ketua Divisi Pengabdian Universitas Muhammadiyah Magelang yang telah memberikan bantuan pendanaan untuk pelaksanaan kegiatan pengabdian ini, selain itu diucapkan terimakasih juga kepada pihak-pihak yang telah membantu terlaksananya kegiatan pengabdian ini.

\section{E. DAFTAR PUSTAKA}

Febrian, J. 2002. Kamus Komputer dan Istilah Teknologi Informasi, CV. Informatika, Bandung.

Kadir, A. 2005. Pengenalan Sistem Informasi, Penerbit Andi. Yogyakarta. 205

Sumadi, S. Putra, R. Ardhiarisca, O. 2018. Pelatihan Tata Kelola Keuangan pada Gabungan Kelompok Tani "Maju Mapan” di Kabupaten Jember Jurnal Pengabdian Masyarakat JDINAMIKA, Vol. 3, No. 2, Desember 2018: 166-170.

Sutrisno. 2013. Manajemen Keuangan :

Teori Konsep \& Aplikasi. Ekonesia. Yogyakarta. 9.

Ikhwani, Y. Budiman, H. Rasyidan, M. 2015. Pelatihan Aplikasi Microsoft Word 2013 Pada SMP H. A. Johansyah. A Banjarmasin, Jurnal AlIkhlas Volume 1 Nomor 1, Oktober $2015: 11-14$ 